\title{
Antibacterial and antioxidant potential of ethyl acetate extract from Streptomyces AIA12 and AIA17 isolated from gut of Chanos chanos
}

\author{
MUHAMMAD ALFID KURNIANTO ${ }^{1,2}$, HARSI DEWANTARI KUSUMANINGRUM ${ }^{3, \bullet}$, \\ HANIFAH NURYANI LIOE ${ }^{3}$, EKOWATI CHASANAH ${ }^{4}$ \\ ${ }^{1}$ Food Science Program, Graduate School, Institut Pertanian Bogor. Jl. Raya Dramaga, IPB University Campus, Bogor 16680, West Java, Indonesia \\ ${ }^{2}$ Department of Food Technology, Faculty of Engineering, Universitas Pembangunan Nasional "Veteran” Jawa Timur. Jl. Rungkut Madya, Gunung \\ Anyar, Surabaya 60294, East Java, Indonesia \\ ${ }^{3}$ Department of Food Science and Technology, Faculty of Agricultural Engineering and Technology, Institut Pertanian Bogor. Jl. Lingkar Akademik, IPB \\ University Campus, Bogor 16680, West Java, Indonesia. Tel.: +62-251-8626725, `email: h_kusumaningrum@apps.ipb.ac.id \\ ${ }^{4}$ Research and Development Center for Marine and Fisheries Product Processing and Biotechnology, Ministry of Marine and Fisheries. JL. K.S. Tubun, \\ Petamburan VI, Slipi, Jakarta Pusat 10260, Jakarta, Indonesia
}

Manuscript received: 18 May 2021. Revision accepted: 14 July 2021

\begin{abstract}
Kurnianto MA, Kusumaningrum HD, Lioe HN, Chasanah E. 2021. Antibacterial and antioxidant potential of ethyl acetate extract from Streptomyces AIA12 and AIA17 isolated from gut of Chanos chanos. Biodiversitas 22: 3196-3206. Streptomyces has been recognized as a promising and productive source of antibacterial and antioxidant compounds. The phenotypic and genomic characterizations indicated AIA12 and AIA17 are closely related to the S. globisporus ARGB01 and S. misionensis S1-SC15, respectively. Incubation on yeast-malt extract broth for nine days (AIA12) and 11 days (AIA17) proved to be the best growth medium and optimum antibacterial production time for these two strains. Crude-extract of extracellular secondary metabolites, obtained by ethyl acetate extraction, demonstrated broad-spectrum inhibitory activity against Pseudomonas aeruginosa InaCC B52, Staphylococcus aureus ATCC 25923, Bacillus cereus ATCC 10876, Escherichia coli ATCC 25922, Salmonella Typhimurium ATCC 14028, and Listeria monocytogenes with minimum inhibitory and minimum bactericidal concentrations from 2.5 to 0.31 and 5.0 to $0.31 \mathrm{mg} \mathrm{mL}^{-1}$, respectively. Evaluation of antioxidant showed AIA17 crude-extract had moderate DPPH scavenging and antioxidant activities of $65.122 \% \pm 0.56$ and $28.178 \pm 0.24 \mathrm{mg}$ ascorbic acid equivalent antioxidant capacity (AEAC $\mathrm{g}^{-1}$ ), respectively. The identification of compounds through profiling with RP-HPLC showed optimum absorbance at 210 and $214 \mathrm{~nm}$, which showed the presence of peptide groups in the constituent compounds' molecular structure. These findings indicate that Chanos chanos-derived Streptomyces produces valuable bioactive compounds with various promising biological activities.
\end{abstract}

Keywords: Actinobacteria, antimicrobial, estuarine fish, gut-microbiota, milkfish

\section{INTRODUCTION}

Estuarine is the confluence between two types of waters with different salinity levels, seawater and river. These encounters create environmental stresses such as fluctuations in salinity levels and continuous tidal gradients (James et al. 2007; Nett et al. 2009; Priya dan Anandaraj 2016). Continuous exposure to this condition can promote the adaptation of metabolic pathways and the synthesis of various secondary metabolites, especially from specific metabolic processes that are only possible if the bacteria are in abnormal conditions or conditions to maintain bacterial survival (Dholakiya et al. 2017; Tan et al. 2019). This is interesting, considering that various new molecules with potential biological activity may be obtained from unusual sources (Tan et al. 2019). One of the microorganisms found in this unique environment is Streptomyces sp. (Kurnianto et al. 2020a).

Streptomyces is bacteria with the widest relative abundance throughout the ecosystem that can interact or form a symbiosis with eukaryotic hosts (Flórez et al. 2015; Lewin et al. 2017; Sivalingam et al. 2019). This ability provides bacteria with the physiological capacity and genetic potential to express up to twenty types of prospective metabolites with various interesting bioactivities (Janardhan et al. 2014; Dholakiya et al. 2017; Tan et al. 2019). Streptomyces produce various secondary metabolites with bioactive properties, especially antibacterial currently of clinical importance, such as chloramphenicol, clindamycin, lincomycin, daptomycin, fosfomycin, kanamycin, and neomycin (Quinn et al. 2020). Continuous exploration of various environmental sources, especially unexplored or underexploited environments, has uncovered various new antibacterial bioactive molecules (Sivalingam et al. 2019). The ribosomally synthesized and post-translationally modified peptides (RiPPs) constitute a large class of antibacterial peptides with a high degree of structural diversity and less well-understood bioactivity produced by Streptomyces (Arnison et al. 2014; Tan et al. 2019). Some of the Streptomyces RiPPs that have been reported are grisemycin (S. griseus), bottromycin (S. bottropensis), and cinnamycin (S. cinnamoneus) (Claesen dan Bibb 2011; Ökesli et al. 2011; Huo et al. 2012). Apart from antibacterial, further exploration also revealed that Streptomyces could produce metabolites with antioxidant activity when grown in oxidative stress conditions (Janardhan et al. 2014; Sivalingam et al. 2019). 
Environmental conditions and exposure to abiotic stress are thought to trigger the development of survival mechanisms in the form of the ability to produce metabolites that can act as antioxidants to neutralize the environment induced by oxidative stress (Dholakiya et al. 2017; Tan et al. 2019b).

Previous studies have isolated 38 isolates from the gut of milkfish (Chanos chanos). Twenty-two isolates were found to have antibacterial activity (Kurnianto et al. 2020a). Preliminary screening using cross streak and double-layer diffusion method showed AIA12 and AIA17 had potential inhibitory activity against $S$. aureus, B. cereus and $E$. coli. Extraction using ethyl acetate has revealed the potential antibacterial activity of four Streptomyces isolated from milkfish (Chanos chanos) (Kurnianto et al. 2020b). Streptomyces is thought to produce semi-polar antibacterial compounds so that these compounds can be extracted by solvents with the same polarity as ethyl acetate. The study of Parthasarathi et al. (2013) showed the effectiveness of ethyl acetate in extracting Streptomyces antibacterial compounds, in which ethyl acetate extract exhibited better antibacterial activity than other solvents. In this study, we investigated two isolates of Streptomyces associated with Chanos chanos, AIA12, and AIA17, which are thought to produce peptide-containing metabolites with potential antibacterial and antioxidant activity

\section{MATERIALS AND METHODS}

\section{Preparation of Isolates}

Two isolates of AIA12 and AIA-17 were isolated from the gut of milkfish (Chanos chanos). Lyophilized isolates were regenerated by inoculating them on the yeast extractmalt extract (YEME) broth and incubated for 3 days at $30^{\circ} \mathrm{C}$. The isolates were cultivated in YEME agar and incubated at $30^{\circ} \mathrm{C}$ for 14 days. Test bacteria, i.e., Staphylococcus aureus ATCC 25923, Bacillus cereus ATCC 10876, Pseudomonas aeruginosa InaCC B52, Salmonella enterica serovar Typhimurium ATCC 14028, Listeria monocytogenes and Escherichia coli ATCC 25922 were grown on tryptic soy broth (Oxoid, UK) and incubated for 24 hours at $37^{\circ} \mathrm{C}$.

\section{Phenotypic characterization}

The macroscopic morphology of the isolate's colony was analyzed using six different media, i.e., YEME agar, nutrient broth (NB; Oxoid, UK), tryptic soy broth (TSB; Oxoid, UK), starch casein agar (SCA; Himedia, India), actinomycetes isolation agar (AIA; Difco BD, USA), and tryptone-yeast extract (ISP-1; Himedia, India). In macroscopic morphology, three parameters (production of soluble pigment, and color of the aerial and mycelium substrate) were observed. The microscopic morphology was analyzed using the coverslip method described by Shirling and Gottlieb (1966). Gram staining was conducted following Cerny (1978). The effect of $\mathrm{NaCl}$ and $\mathrm{pH}$ concentrations on isolates were evaluated by inoculating isolates at $\mathrm{pH} 5.0-10.0$ and $2-12 \% \mathrm{NaCl}$ concentrations on inorganic-salt-starch agar (ISP-4; Himedia, India) (Singh et al. 2014b). The activity of hemolysin-producing isolates was analyzed by inoculating each isolate on sheep's blood agar (Bernal et al. 2015). The utilization of carbon sources was evaluated by inoculating the isolates on a medium with $1 \%$ concentration of carbon sources (Pridham and Gottlieb 1948). The API 20 kit (Biomerieux, France) was used to determine the ability and response of isolates in producing, hydrolyzing or utilizing certain compounds or enzymes (Nurkanto and Agusta 2015). All tests were carried out on the $7^{\text {th }}$ day after incubation at $30^{\circ} \mathrm{C}$.

\section{DNA extraction, 16S rRNA PCR, and phylogenetic analysis}

The AIA12 and AIA17 isolates were incubated in YEME broth, incubated at $30^{\circ} \mathrm{C}$ for 7 days, and centrifuged for $15 \mathrm{~min}$ at $10,000 \mathrm{rpm}$ to separate cell biomass and supernatant. For the DNA extraction process, cell biomass was used according to Pitcher et al. (1989). The DNA extract was amplified using PCR with primers 9F (5'GAGTTTGATCCTGGCTCAG) and 1541R (5'AAGGAGGTGATCCAGCC), evaluated by $1 \%$ (w/v) electrophoresis and sequencing. The sequencing data results were processed to obtain complementary sequences (contig) with CLUSTAL-X, converted to FASTA, and homology identified using the BLASTN program (https://blast.ncbi.nlm.nih.gov/Blast.cgi) provided by NCBI (www.ncbi.nlm.nih.gov) with a search set database nt (nucleotide collection), and a selection optimize program for highly similar sequences (megablast). The analysis of phylogenetic tree was determined using MEGA 6 with the Neighbor-Joining (NJ) algorithm and 1000 bootstraps resampling for assessing clade support from the built tree topology (Andayani et al. 2015; Felsentein 1985).

\section{Determination of optimum condition for secondary metabolite production}

Three different production media, i.e., nutrient broth with glucose (Farris et al. 2011), YEME broth (Shirling and Gottlieb, 1966), and gause's synthetic broth (Dholakiya et al. 2017) were used to determine the optimum production media. Each isolate was inoculated on the medium and incubated for 10 days at $30^{\circ} \mathrm{C}$. Harvesting of the supernatant was carried out by centrifugation (Hermle, Germany) for $15 \mathrm{~min}$ at $8000 \mathrm{rpm}$. Determination of the optimum time for secondary metabolite synthesis was carried out by measuring the dry weight of bacteria cell biomass and the supernatant's antibacterial activity from day 3 to day 11 (each 48-h interval) (Dholakiya et al. 2017). The microdilution assay against Escherichia coli ATCC 25922 and Staphylococcus aureus ATCC 25923 was used to test the antibacterial activity of each supernatant (Memarpoor-Yazdi et al. 2012). The low optical density value $\left(\mathrm{OD}_{600}\right)$ in the microdilution assay demonstrated higher inhibitory activity.

\section{Production and extraction of secondary metabolites}

Each isolate was inoculated on yeast-malt extract broth and incubated under shaking conditions for $48 \mathrm{~h}$ at $30^{\circ} \mathrm{C}$. Cell biomass was transferred to the optimum production medium and incubated in shaking incubator (New 
Brunswick, Germany) at $180 \mathrm{rpm}$ during the optimum production time (AIA-12 for 11 days and AIA-17 for 9 days) at $30^{\circ} \mathrm{C}$. Cell biomass and supernatant were separated with a centrifuge (Hermle, Germany) at $8000 \mathrm{rpm}$ for 15 min. The supernatant was collected and extracted with ethyl acetate (Merck, Germany) 1:1 (v/v) in a separating funnel. The extraction results were collected and concentrated using a rotary evaporator (Buchi, Switzerland) to acquire a crude extract of secondary metabolites. The concentrated crude extract was reconstituted in DMSO 2\% (Merck, Germany), and stock concentrations were obtained at $10 \mathrm{mg} \mathrm{mL} \mathrm{mL}^{-1}$ (Gebreyohannes et al. 2013; Zothanpuia et al. 2017).

\section{Quantitative assay for antibacterial activity}

Crude extracts of secondary metabolites were prepared. A total of $20 \mu \mathrm{L}$ of crude-extract was dripped on a blankdisc with $6 \mathrm{~mm}$ diameter (Oxoid, UK), left to stand for a while so that the crude extract was absorbed into the disc, then placing the blank-disk on the Mueller Hinton agar's surface (MHA; Oxoid, UK) which had previously been inoculated by test bacteria. Incubation was carried out for $24 \mathrm{~h}$ at $37^{\circ} \mathrm{C}$. The antibacterial activities of the crude extract were assessed after completing the incubation process by measuring the inhibitory zone $(\mathrm{mm})$ formed around the disc (Balouiri et al. 2016).

\section{Minimum inhibitory and minimum bactericidal concentration assay}

A microdilution assay with a 96-well microtiter plate was used to measure the minimum inhibitory concentration (MIC) value. Crude-extract of the secondary metabolite was prepared with concentrations of $10,5.0,2.5,1.25$, $0.625,0.312,0.156,0.078,0.04,0.02,0.009$, and $0.004 \mathrm{mg}$ $\mathrm{mL}^{-1}$. A total of $100 \mu \mathrm{L}$ crude extract was put into each well of a microtiter plate that had previously been given $100 \mu \mathrm{L}$ Mueller Hinton broth (MHB; Himedia, India). Next, $100 \mu \mathrm{L}$ of test bacteria with a density of $1 \times 10^{6} \mathrm{CFU}$ $\mathrm{mL}^{-1}$ was inserted into each well of a microtiter plate and were incubated at $37^{\circ} \mathrm{C}$ for $24 \mathrm{~h}$. The Ampicillin $(10 \mu \mathrm{g}$ $\mathrm{mL}^{-1}$ ) and DMSO $2 \%$ were used as positive and negative controls, respectively. 96-well microtiter plates were incubated for $24 \mathrm{~h}$ at $37^{\circ} \mathrm{C}$. The minimum bactericidal concentration (MBC) was analyzed by inoculating the MIC test results (three wells with the lowest concentration) onto Mueller Hinton agar (MHA; Himedia, India) and incubating for $24 \mathrm{~h}$ at $37^{\circ} \mathrm{C}$ (Balouiri et al. 2016).

\section{Preliminary analysis of antioxidant potential using the DPPH method}

The potential antioxidant analysis was conducted by combining $2 \mathrm{~mL}$ of DPPH solution (in methanol) in a dark tube with $2 \mathrm{~mL}$ of crude extract of each isolate or standard (ascorbic acid). The mixture solution was incubated at room temperature for $30 \mathrm{~min}$ in the dark. Furthermore, the OD solution was measured using a UV-Vis spectrophotometer at $517 \mathrm{~nm}$ (Janardhan et al. 2014). The radical scavenging operation percentage of DPPH was determined using the formula:

$$
\text { DPPHradical scawenging activity }(86)=\frac{A_{Q}-A_{8}}{A_{Q}} \times 100
$$

Where: $A_{c}$ was the absorbance of DPPH control, $A_{s}$ was the absorbance of DPPH in the presence of extract/ standard.

\section{RP-HPLC Profile crude-extracts of secondary metabolites}

Twenty microliters of crude extract of secondary metabolites dissolved in methanol were injected into Agilent 1200 Series HPLC with XDC-C-18 column $(4.60 \times$ $150 \mathrm{~mm} ; 5 \mu \mathrm{m})$. The analysis process used an elution gradient of $10 \%$ A-50\% B (A Aceronitril, B Water), for 30 minutes with a flow rate of $0.5 \mathrm{~mL}$ per minute. Multiwavelength UV-Vis detectors (MWD) are used to detect compounds at 210 and $214 \mathrm{~nm}$ for detection of carboxyl groups and peptide bonds, and 254 and $276 \mathrm{~nm}$ for detection of aromatic groups (Djinni et al. 2014).

\section{Statistical analysis}

The experiment was repeated three times and expressed as mean \pm SD (standard deviation). One-way analysis of variance (ANOVA) and other data analysis was performed using the SPSS 18.0 program, in which the Duncan multiple range test ( $95 \%$ confidence interval) was used to determine differences that were significantly different between means.

\section{RESULTS AND DISCUSSION}

\section{Phenotypic characterization of isolates}

The morphological characteristics of AIA12 and AIA17 grown on six different media were found to be varied. YEME agar was the best growth media. In this media, AIA12 and AIA17 formed gray and white aerial mycelium, and cream-light brown and brown substrates mycelium, respectively (Figures 1.A.1-2 and 1.B.1-2; Table 1). AIA17 isolates also showed their ability to produce brown soluble pigments. Observations using a light microscope also showed that AIA12 had a straight spore chain, while AIA17 had a spiral spore chain (Figures 1.A.3 and 1.B.3).

Physiological characteristics showed both isolates grew well on a medium with a $\mathrm{pH}$ of 7.0 and a $\mathrm{NaCl}$ concentration of $8 \%$, and did not show hemolytic activity (Table 2). The biochemical characteristics also showed that the isolate can hydrolyze starch, produce specific enzymes (e.g., urease, $\beta$-Galactosidase, and tryptophan deaminase), and utilize several carbon sources such as glucose, saccharose, amygdaline, and arabinose (Table 2). 


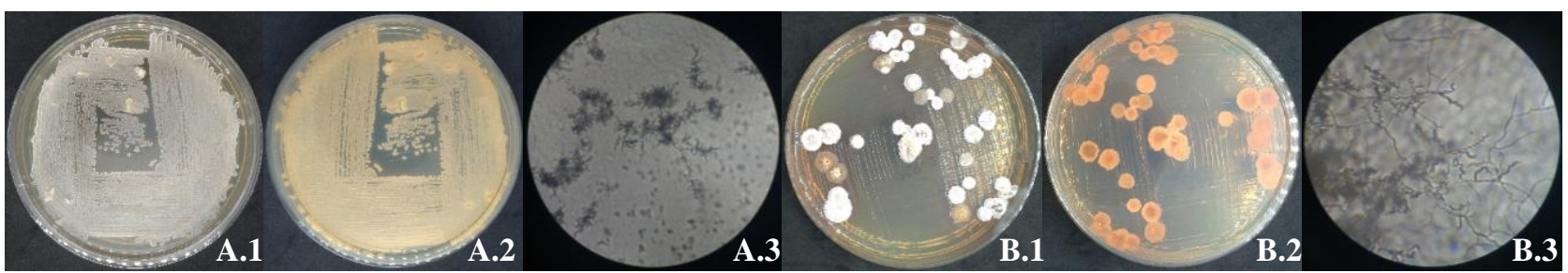

Figure 1. Morphological appearance of Streptomyces sp. AIA12 dan AIA17 on YEME agar; A: Streptomyces AIA12; B: Streptomyces AIA17; 1: Aerial Mycelium; 2: Substrate Mycelium; 3: Microscopic appearance (1000x)

Table 1. Cultural characteristic of Streptomyces sp. AIA12 and AIA17 on a different medium

\begin{tabular}{|c|c|c|c|c|c|c|}
\hline \multirow{2}{*}{ Properties } & \multicolumn{6}{|c|}{ Growth medium } \\
\hline & SCA & AIA & ISP-1 & YEME & NB & TSB \\
\hline \multicolumn{7}{|l|}{ AIA12 } \\
\hline Growth & Good & Good & Poor & Very Good & Poor & Poor \\
\hline Aerial mycelium & Beige & White & - & White & White & - \\
\hline Substrate mycelium & White-Beige & Cream-light brown & - & Cream-light brown & White & - \\
\hline Pigment production & - & - & - & - & - & - \\
\hline \multicolumn{7}{|l|}{ AIA17 } \\
\hline Growth & Poor & Good & Good & Very Good & Poor & Poor \\
\hline Aerial mycelium & Grey & White & White & White & Yellow & - \\
\hline Substrate mycelium & Grey & Cream-light brown & White & Brown & Yellow & Beige \\
\hline Pigment production & - & - & - & Brown & - & - \\
\hline
\end{tabular}

Note: SCA (strach casein agar); AIA (actinomycete isolation agar); ISP-1 (tryptone-yeast extract); YEME (yeast extract-malt extract); NB (nutrient broth); TSB (tryptic soy broth); (-): not formed

Table 2. Biochemical and physiological characteristics of Streptomyces sp. AIA12 and AIA17

\begin{tabular}{|c|c|c|}
\hline Properties & AIA12 & AIA17 \\
\hline Pigment production* & Not produce & Brown \\
\hline $\mathrm{pH}$ range for growth* & $5.0-9.0$ & $6.0-9.0$ \\
\hline pH optimum for growth* & 7.0 & 7.0 \\
\hline $\mathrm{NaCl}$ tolerance* & $8 \%$ & $6 \%$ \\
\hline Hemolytic activity & Negative & Negative \\
\hline \multicolumn{3}{|l|}{ Enzyme production } \\
\hline Tryptophan deaminase & + & + \\
\hline$\beta$-Galactosidase & + & - \\
\hline Urease & - & - \\
\hline Ornithine decarboxylase & - & - \\
\hline Arginine dihydrolase & - & - \\
\hline Gelatinase & + & + \\
\hline Lysine decarboxylase & - & - \\
\hline \multicolumn{3}{|l|}{ Utilization of carbon source } \\
\hline Glucose & - & + \\
\hline Saccharose & - & + \\
\hline Inositol & - & - \\
\hline Mannitol & - & - \\
\hline Rhamnose & - & - \\
\hline Arabinose & + & + \\
\hline Melibiose & - & - \\
\hline Sorbitol & - & - \\
\hline Amygdalin & + & + \\
\hline Starch hydrolysis & + & + \\
\hline Citrate utilization & + & + \\
\hline Voges Proskauer & - & + \\
\hline Indole production & - & - \\
\hline $\mathrm{H}_{2} \mathrm{~S}$ production & - & - \\
\hline
\end{tabular}

\section{Strain Identification using 16S rRNA-based phylogenetic analysis}

The sequencing analysis revealed that AIA12 and AIA17 were composed of 1365 bp and 1363 bp 16S rRNA gene sequences, respectively. Both isolates belong to the genus Streptomyces, in which AIA12 was closely related to Streptomyces globisporus ARGB01 (99.56\%), and AIA17 was found to be closely related to Streptomyces misionensis S1-SC15 (99.34\%) (Table 3).

The sequences of isolates were submitted and deposited on GenBank with accession numbers MT774549 and MT774550. Phylogenetic tree analysis of two isolates based on the neighbor-joining showed both isolates had the points at which branches connect (nodes) separated which formed two distinct clades, in which AIA12 formed a single clade with $S$. globisporus ARGB01 and AIA17 formed a single clade with $S$. misionensis S1-SC15. The resulting phylogenetic tree construction is shown in Figure 2.

\section{Optimum production condition}

The optimum production medium was determined based on the highest inhibitory activity. YEME was chosen as the best production medium. Microdilution test results showed that the $\mathrm{OD}_{600}$ of test bacteria $(S$. aureus and $E$. coli) exposed to YEME supernatants was lower than cultures exposed to other media supernatants (Figure 3). The lower optical density indicated the higher inhibitory activity against test bacteria. Statistical analysis of $S$. aureus $\mathrm{OD}_{600}$ growth also showed that supernatant exposure to YEME produced significantly lower $\mathrm{OD}_{600}$ than other media. However, different results were found in the $\mathrm{OD}_{600}$ growth of $E$. coli, which were not significantly different from other media. 
The measurement of the dry weight of bacterial cell biomass indicated the phases of bacterial growth, in which the beginning and the end of the growth phase can be seen from the increase in cell biomass weight (Figure 4). Both isolates ended the lag phase and entered the exponential phase (log phase) on day five. In AIA12, the exponential phase ends on the $9^{\text {th }}$-day and begins to enter the stationary phase on the $11^{\text {th }}$-day. Meanwhile, in AIA17, this phase was still ongoing until the $11^{\text {th }}$-day because there was still a slight increase in cell biomass. In the antibacterial activity test, the $\mathrm{OD}_{600}$ value of the two tested bacteria began to decrease on the $5^{\text {th }}$-day of the incubation period or in the exponential growth phase. The $\mathrm{OD}_{600}$ value continues to decline with the incubation time and changes in the growth phase. The decrease in $\mathrm{OD}_{600}$ value indicated an increase in the inhibitory activity of the tested bacteria. In AIA12, optimal antibacterial activity was obtained on day 11 or when the bacteria were in the stationary phase. Meanwhile, in AIA17, optimal antibacterial activity was obtained on day 9 or at the exponential phase (Figure 4). These conditions were used for further investigation described below.

\section{The antibacterial activity of secondary metabolite crude extracts}

Promising wide-spectrum antibacterial activity was demonstrated for the crude extracts of secondary metabolites AIA12 and AIA17. The two crude-extract tests showed the highest inhibition zone was produced in B. cereus, which was $18.5 \pm 0.2 \mathrm{~mm}$ on AIA12 and $24.7 \pm 0.4 \mathrm{~mm}$ on AIA17. Meanwhile, the lowest inhibition zone in the two crude extracts was produced in E. coli, which was $6.3 \pm 0.6$ $\mathrm{mm}$ in AIA12 and 12.0 $\pm 0.3 \mathrm{~mm}$ in AIA17 (Table 4).

The microdilution assay on 96-well microtiter plates returned MIC values between 2.50 and $0.31 \mathrm{mg} \mathrm{mL}^{-1}$ (Table 5). In AIA12, the lowest MIC values were detected in $P$. aeruginosa and $B$. cereus $\left(0.15 \mathrm{mg} \mathrm{mL}^{-1}\right)$. Meanwhile, in AIA17, the lowest MIC were demonstrated in E. coli, $P$. aeruginosa, $S$ Typhimurium, $S$. aureus, and B. cereus $(0.31$ $\mathrm{mg} \mathrm{mL}^{-1}$ ). In the MBC test, it was known that the MBC values obtained ranged from $5.00-0.31 \mathrm{mg} \mathrm{mL}^{-1}$, with the lowest MBC values in AIA12 with $P$. aeruginosa and $B$. cereus $\left(0.31 \mathrm{mg} \mathrm{mL}^{-1}\right)$ and AIA17 with in E. coli, P. aeruginosa, $S$. Typhimurium, and B. cereus $\left(0.62 \mathrm{mg} \mathrm{mL}^{-1}\right)$ (Table 5).

Table 3. Alignment results of the $16 \mathrm{~S}$ rRNA gene sequence on Streptomyces sp. AIA12 and AIA17

\begin{tabular}{|c|c|c|c|c|c|c|}
\hline Isolates & BLAST result & $\begin{array}{c}\text { Accession } \\
\text { number }\end{array}$ & $\begin{array}{c}\text { Max query } \\
\text { cover }(\%)\end{array}$ & Max score & Total score & Max. Ident (\%) \\
\hline \multirow[t]{3}{*}{ AIA12 } & Streptomyces globisporus strain ARGB01 & MH384424.1 & $100 \%$ & 2484 & 2484 & $99.56 \%$ \\
\hline & Streptomyces atratus strain $1536 \mathrm{C} 13 \mathrm{H}$ & MK484228.1 & $100 \%$ & 2403 & 2403 & $98.47 \%$ \\
\hline & Streptomyces fradiae strain MB-51 & MF686458.1 & $100 \%$ & 2375 & 2375 & $97.88 \%$ \\
\hline \multirow[t]{3}{*}{ AIA17 } & Streptomyces misionensis strain S1-SC15 & AB819392.1 & $100 \%$ & 2483 & 2483 & $99.34 \%$ \\
\hline & Streptomyces colonosanans strain MUSC 93 & NR169464.1 & $100 \%$ & 2427 & 2427 & $98.61 \%$ \\
\hline & Streptomyces koyangensis strain $1234 \mathrm{C} 7 \mathrm{H}$ & MK484232.1 & $100 \%$ & 2375 & 2375 & $97.88 \%$ \\
\hline
\end{tabular}

Table 4. Zone inhibition (mm) of crude-extract Streptomyces sp. AIA12 and AIA17 by disc-diffusion method

\begin{tabular}{lcccc}
\hline \multirow{2}{*}{ Bacterial test } & \multicolumn{3}{c}{ Inhibition zone (mm) } \\
\cline { 2 - 5 } & AIA12 & AIA17 & Control (+) & Control (-) \\
\hline Escherichia coli ATCC 25922 & $6.3 \pm 0.6$ & $10.0 \pm 0.3$ & $27.0 \pm 0.1$ & $0 \pm 0$ \\
Staphylococcus aureus ATCC 25923 & $6.7 \pm 0.1$ & $19.7 \pm 0.5$ & $23.5 \pm 0.2$ & $0 \pm 0$ \\
Salmonella Typhimurium ATCC 14028 & $14.5 \pm 0.3$ & $15.0 \pm 0.3$ & $35.5 \pm 0.5$ & $0 \pm 0$ \\
Listeria monocytogenes & $13.2 \pm 0.4$ & $16.2 \pm 0.4$ & $24.5 \pm 0.5$ & $0 \pm 0$ \\
Pseudomonas aeruginosa InaCC B52 & $16.5 \pm 0.1$ & $12.0 \pm 0.3$ & $18.5 \pm 0.3$ & $0 \pm 0$ \\
Bacillus cereus ATCC 10876 & $18.5 \pm 0.2$ & $24.7 \pm 0.4$ & $32.0 \pm 0.4$ & $0 \pm 0$ \\
\hline
\end{tabular}

Note: The value was mean zone of inhibition $(\mathrm{mm}) \pm$ standard deviation (SD) from three replication; Control (+): Ampicillin $10 \mu \mathrm{g} \mathrm{mL}^{-}$

1; Control (-): DMSO 2\%

Table 5. MIC and MBC value of Streptomyces sp. AIA12 and AIA17 crude extract $\left(10 \mathrm{mg} \mathrm{mL}^{-1}\right)$

\begin{tabular}{|c|c|c|c|}
\hline Isolates & Bacterial Test & $\operatorname{MIC}\left(\mathrm{mg} \mathrm{mL}^{-1}\right)$ & $\operatorname{MBC}\left(\mathrm{mg} \mathrm{mL}^{-1}\right)$ \\
\hline AIA12 & $\begin{array}{l}\text { Staphylococcus aureus ATCC } 25923 \\
\text { Bacillus cereus ATCC } 10876 \\
\text { Listeria monocytogenes } \\
\text { Escherichia coli ATCC } 25922 \\
\text { Pseudomonas aeruginosa InaCC B52 } \\
\text { Salmonella Typhimurium ATCC } 14028\end{array}$ & $\begin{array}{l}2.50 \\
0.15 \\
2.50 \\
2.50 \\
0.15 \\
1.25\end{array}$ & $\begin{array}{l}5.00 \\
0.31 \\
5.00 \\
5.00 \\
0.31 \\
2.50\end{array}$ \\
\hline AIA17 & $\begin{array}{l}\text { Staphylococcus aureus ATCC } 25923 \\
\text { Bacillus cereus ATCC } 10876 \\
\text { Listeria monocytogenes } \\
\text { Escherichia coli ATCC } 25922 \\
\text { Pseudomonas aeruginosa InaCC B52 } \\
\text { Salmonella Typhimurium ATCC } 14028\end{array}$ & $\begin{array}{l}0.31 \\
0.31 \\
0.62 \\
0.31 \\
0.31 \\
0.31\end{array}$ & $\begin{array}{l}2.50 \\
0.62 \\
1.25 \\
0.62 \\
0.62 \\
0.62\end{array}$ \\
\hline
\end{tabular}

Note: MIC: Minimum inhibitory concentration; MBC: Minimum bactericidal concentration 


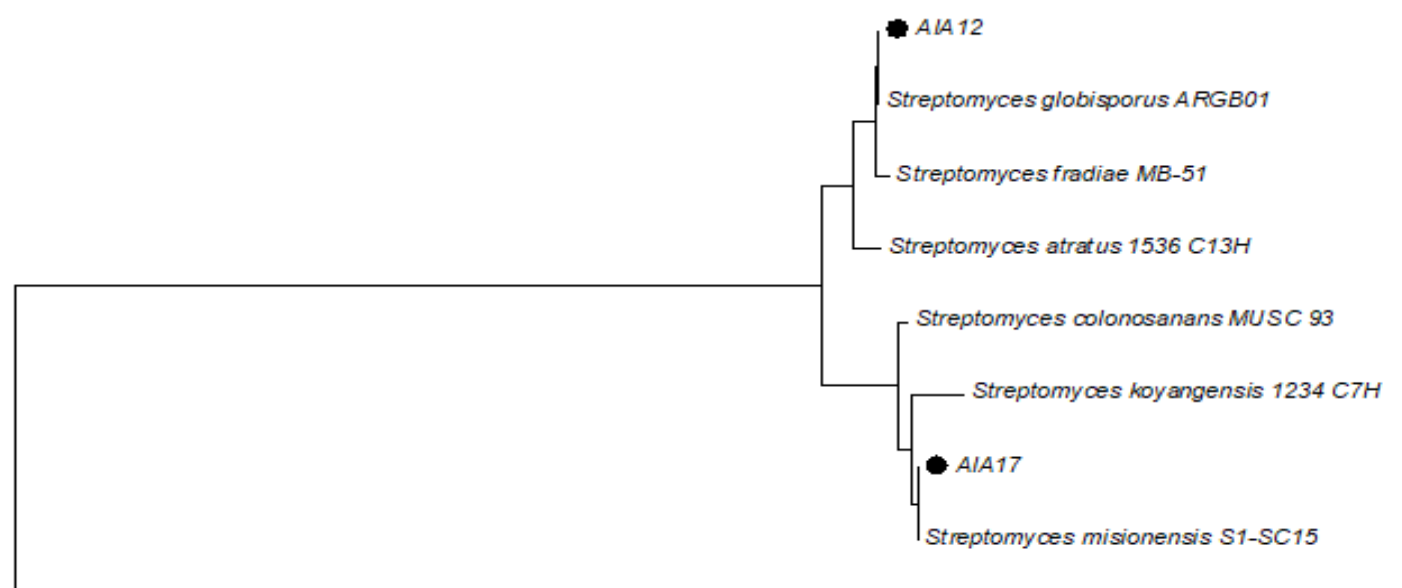

Staphylococcus piscifermentans BSLST44

0.05

Figure 2. Phylogenetic tree of Streptomyces sp. AIA12 and AIA17 were constructed with MEGA 6.0

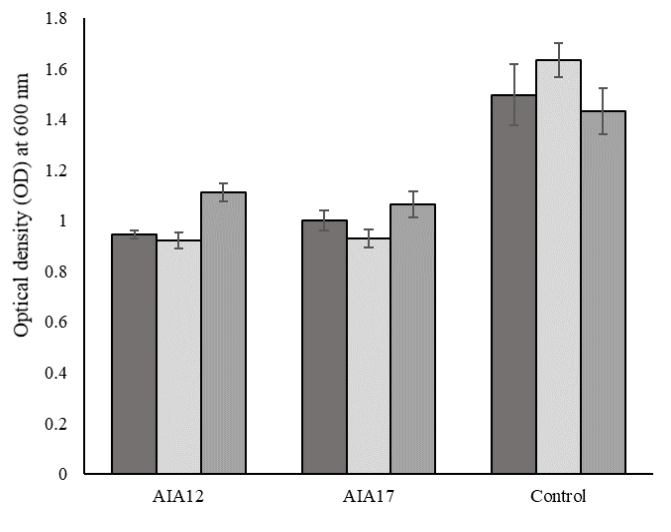

A

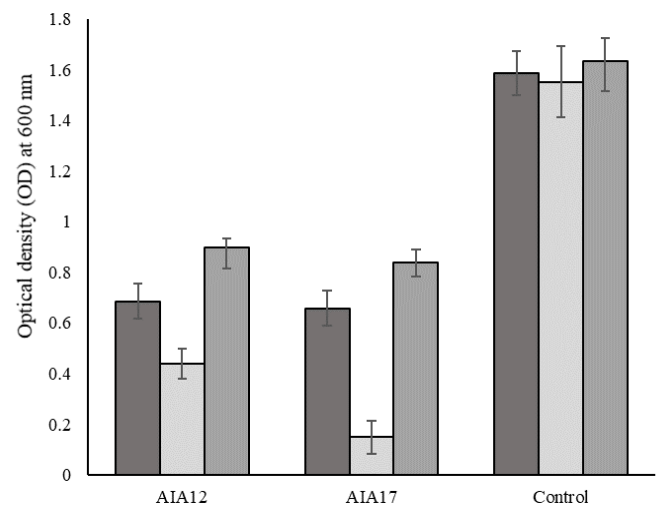

B

Figure 3. The OD600 value of E. coli (A) and S. aureus (B) exposed to supernatant AIA12 and AIA17 grown on different production medium (NBG, GSB, and YEME); Control: E. coli and S. aureus cultured in growth medium without exposing to AIA-12 and AIA17 supernatants

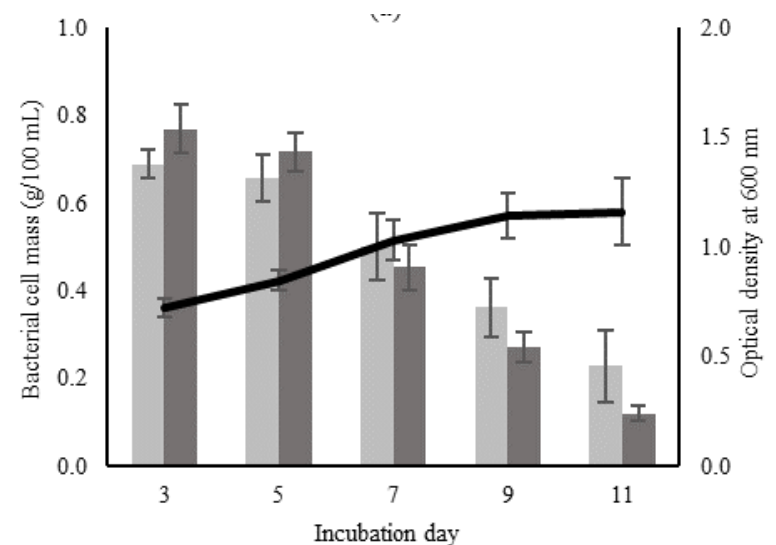

A

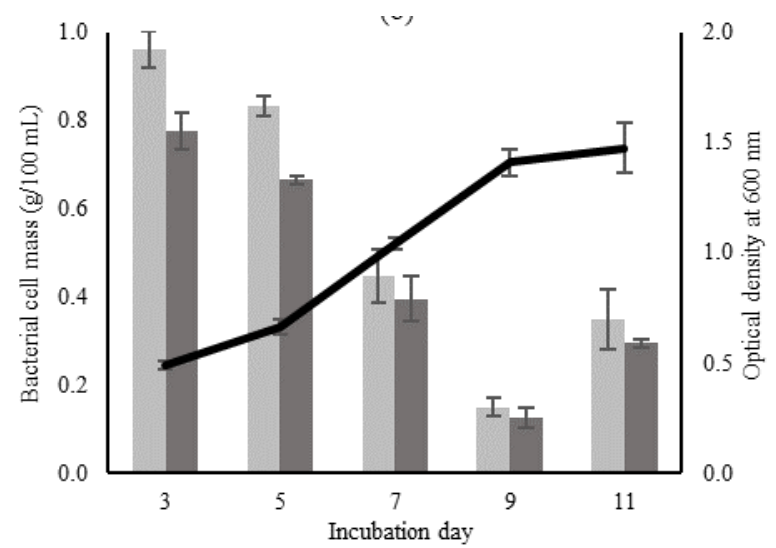

E. coli

Figure 4. Growth curve of AIA12 (a) and AIA17 (b) based on the bacterial cell biomass during incubation time and the OD 600 value of E. coli and S. aureus exposed to supernatant AIA12 (a) and AIA17 (b) during the incubation time 


\section{Potential antioxidant activity}

The DPPH method was chosen since it is the most common and reasonably simple approach for measuring the radical scavenging activity of active biological particles. The results of DPPH radical scavenging activity and antioxidant activity of both extracts are presented in Table 6. Our results showed that the percentage of DPPH radical scavenging activity was directly proportional to the antioxidant activity, where crude extract AIA17 at a concentration of $10 \mathrm{mg} \mathrm{mL}^{-1}$ has higher DPPH radical scavenging activity $(65.12 \% \pm 0.6)$ and potential antioxidant activity $\left(28.2 \pm 0.2 \mathrm{mg} \mathrm{AEAC} \mathrm{g}^{-1}\right)$ than those of AIA12.

\section{Crude-extracts of secondary metabolites profile}

Qualitatively, the two crude extracts of secondary metabolites produce similar RP-HPLC profiles (Figure 5). The similarity in the dominant peaks that appeared at 15 minutes was detected at 210 and $214 \mathrm{~nm}$. More peaks were detected with a more intense area in this wavelength, in which the peaks were scattered at the initial (RT 0-10 min) and mid (RT 10-20 min) retention time. These results indicate that the compounds contained in the crude extract of secondary metabolite experience optimal absorption. Different results were obtained at 254 and $276 \mathrm{~nm}$, where there were only a few peaks with a smaller area. The peaks were also only scattered at the initial (RT 0-10 min) retention time.

Table 6. DPPH free radical scavenging activity of Streptomyces sp. AIA12 and AIA17 crude extract $\left(10 \mathrm{mg} \mathrm{mL}^{-1}\right)$

\begin{tabular}{|c|c|c|}
\hline Extracts & Scavenging activity $(\%)$ & $\begin{array}{l}\text { Antioxidant activity } \\
\quad\left(\mathrm{mg} \text { AEAC } \text { g }^{-1}\right)\end{array}$ \\
\hline AIA12 & $18.95 \pm 0.7^{\mathrm{a}}$ & $7.9 \pm 0.3^{\mathrm{a}}$ \\
\hline AIA17 & $65.12 \pm 0.6^{b}$ & $28.2 \pm 0.2^{b}$ \\
\hline
\end{tabular}

Note: The value was mean percentage of scavenging activity or antioxidant activity \pm standard deviation (SD) from three replication; ( $a$ and $b$ ): different letters in the same column represent significance
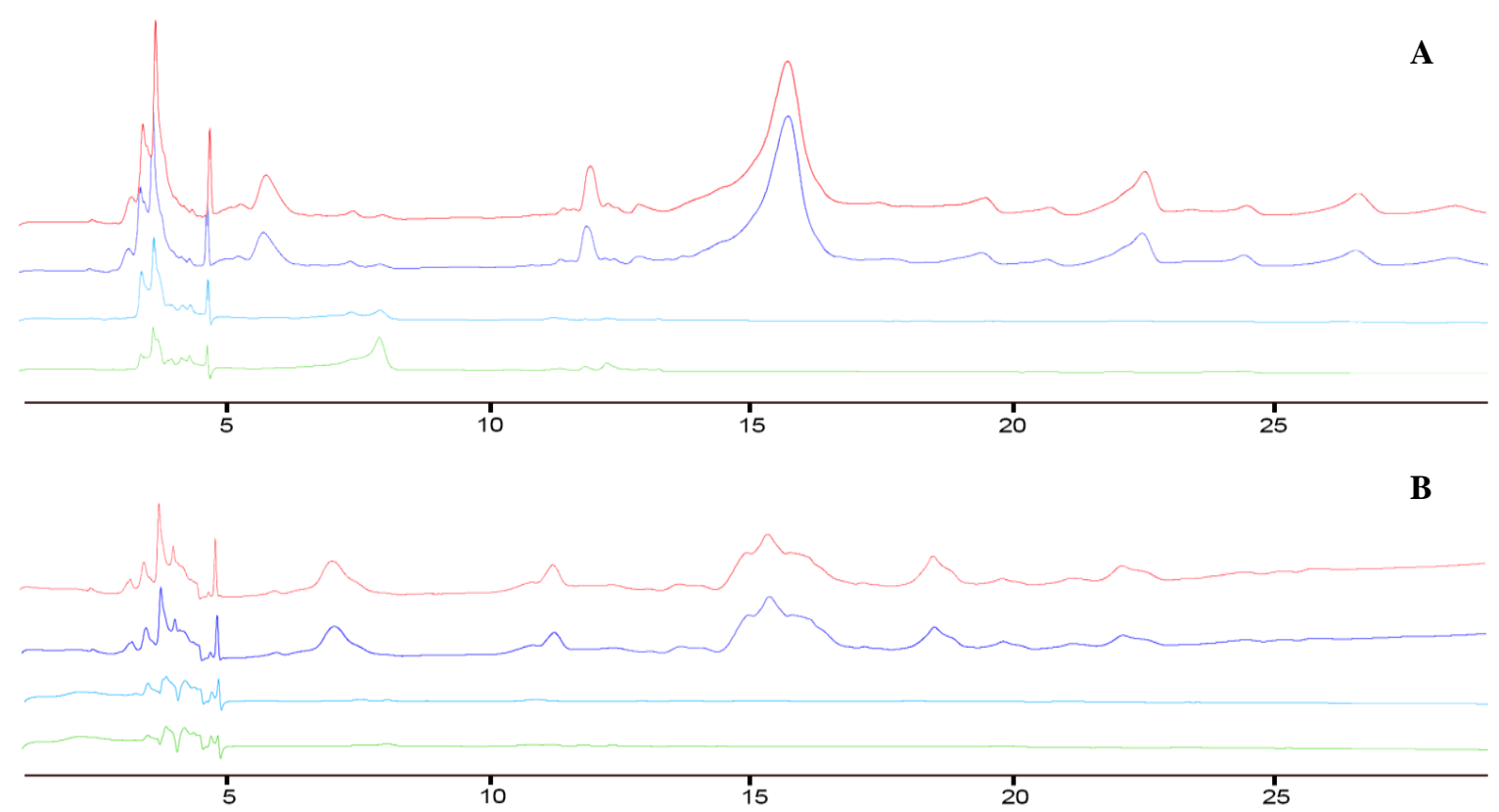

C

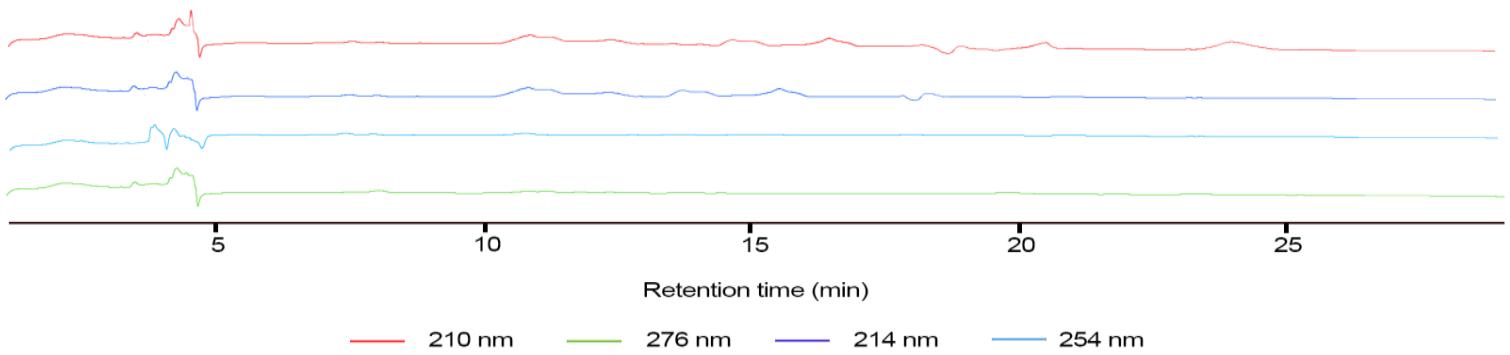

Figure 5. HPLC chromatogram metabolite-crude-extract profile from Streptomyces AIA12 (A) and AIA17 (B) isolates detected at 210 , 214, 254, and $276 \mathrm{~nm}$; HPLC chromatogram control (YEME medium extracted with ethyl acetate) profile detected at 210, 214, 254, and $276 \mathrm{~nm}(\mathrm{C})$ 


\section{Discussion}

Genomic identification confirmed the AIA12 and AIA17 isolates to be closely related to Streptomyces globisporus ARGB01 $(99.56 \%)$ and Streptomyces misionensis (99.34\%), respectively. Typical general morphological features of the Streptomyces genus were seen on the two isolates (Gebreyohannes et al. 2013; Hasani et al. 2014). The study of Abdel-Aziz et al. (2019) showed $S$. globisporus had a whitish-yellow aerial mycelium and pale yellow substrate mycelium, does not produce pigment, had a straight sporophore type, and was able to produce $\mathrm{H}_{2} \mathrm{~S}$. These morphological characteristics were similar to those found in AIA12. The differences were seen in the biochemical characteristics, in which AIA12 was unable to produce $\mathrm{H}_{2} \mathrm{~S}$. Meanwhile, Ser et al. (2016) showed that $S$. misionensis had characteristics such as yellowish-white aerial mycelium and strong yellow substrate mycelium, producing melanoid pigments, being able to grow optimally at $40^{\circ} \mathrm{C}, \mathrm{pH} 7.0$, and $\mathrm{NaCl}$ tolerance $0-6 \%$ (optimum 0-4\%), catalase-positive, negative hemolytic activity, hydrolyze starch, and able to utilize various carbon sources such as glucose, sucrose, raffinose, lactose, and sorbitol.

Despite being in the same species, the morphological characteristics found in S. misionensis were different from those of AIA17. The difference is in the aerial coloration and the mycelium substrate, of which AIA-17 has white and brown colors, respectively. Another difference is in the biochemical characteristics, where AIA17 cannot utilize carbon sources such as sorbitol. This difference was thought to be due to differences in strains between the two isolates, which resulted in differences in the biochemical profile and patterns of carbon source utilization of each isolate (Davelos et al. 2004; Lee et al. 2014; Tan et al. 2019). According to Tan et al. (2019), although the results of genomic identification showed a high similarity of the $16 \mathrm{~S}$ rRNA gene (> 98\%), variations in phenotypic characteristics displayed by isolates were still possible.

Production media is an important factor that must be considered when optimizing antibacterial compounds (Vilches et al. 1990). The findings of the optimization showed that the best production medium was YEME broth. This media consists of yeast extract, malt extract and glucose as a carbon source, a nitrogen source and a source of nutrients needed for bacterial growth. At an optimal composition, this content can increase cell growth and the production of antibacterial compounds (Abdelghani 2017; Al Farraj et al. 2020). Sánchez et al. (2010) stated that the composition of the growth medium with proper nutrition will increase the production of antibacterial. Further research showed that antibacterial compounds began to appear to be synthesized on the $5^{\text {th }}$ day of incubation or the initial logarithmic phase. This can be seen from the decreased optical density (OD) of the test bacteria growth.

In AIA12, the maximum decrease in OD occurred on day 11 (stationary phase). This time is thought to be the optimum time for antibacterial synthesis. These results were similar to Dholakiya et al. (2017), which showed that the incubation period for optimum antibacterial synthesis occurred in the stationary phase. Unlike AIA12, AIA17 showed a maximum decrease in OD on day 9 (late logarithmic phase), and there was another increase in OD on day 11 (stationary phase). This is unusual since secondary metabolite production is common during the ideophase (late log to stationary phase) (Sánchez et al. 2010). Several factors are suspected to cause this, such as genetic factors and environmental factors (Bibb 2005). According to Sanchez dan Demain (2002) environmental factors such as the type and concentration of nutrients (sources of nitrogen, carbon and phosphorus) formulated in culture media affect the regulation of metabolism to produce antibacterial secondary metabolites. The formulation of the production media can also shift the antibacterial production phase (Aharonowitz 1980). Based on the type of nutrition, some nutrients are consumed by bacteria quickly and slowly. Carbon sources such as glucose can be rapidly consumed by bacteria and used to produce cells, while nutrients that are slowly consumed are used to form secondary metabolites (Sánchez et al. 2010). In addition, there are also nutrients that must be consumed before other nutrients are consumed. Kominek (1972) showed that $S$. niveus consumed ammonium sulfate earlier than proline. Although it results in inhibited antibacterial production, it is still necessary that proline is also consumed, which high proline consumption will produce high antibacterial. Some nutrients can suppress or accelerate antibacterial synthesis (Sánchez et al. 2010).

The antibacterial activity analysis of crude extracts of secondary metabolites (extracted by ethyl acetate) AIA12 and AIA17 showed that the compounds responsible for biological activity were extracellular so that they can be extracted and quantified (Passari et al. 2015). Ethyl acetate was used in the extraction process because it had a polarity level that matches the secondary metabolites produced by Streptomyces so that the extraction process is maximized (Kumala et al. 2015). The antibacterial activity analysis showed that the crude-extract AIA12 and AIA17 had broad-spectrum inhibitory activity. In AIA12, these results differ from those of Kaweewan et al. (2018) who found that the antibacterial thiopeptide (Glowbimycin) and Radamycin produced by $S$. globispours NRRL B-2709 were able to inhibit only Gram-positive bacteria ( $B$. subtilis, S. aureus, and M. luteus). In AIA17, the results of this study are similar to Saadouli et al. (2020), which showed that $S$. misionensis V16R3Y1 is capable of producing broad-spectrum antimicrobial peptides, which have dual roles as antibacterial and antifungal. The content of compounds and the level of purity of different compounds are thought to cause the differences in antibacterial activity shown (Umerska et al. 2018). The study Zhang et al. (2009) showed that the purification process of pentocin 31-1 (adsorption at $\mathrm{pH} 4.5$ and release at $\mathrm{pH}$ 7.0, and Sephadex G-10 gel filtration chromatography) was able to increase its antibacterial activity up to 1381 times compared to its activity as cell culture supernatant.

Natural extracts derived from microorganisms have not been widely used and can contain many antioxidants 
(Huang et al. 2005; Tan et al. 2019). The study results showed that crude-extract AIA17 $\left(10 \mathrm{mg} \mathrm{mL}^{-1}\right)$ had $65.12 \%$ free-radicals scavenging activity. These results indicate a moderate antioxidant potential. Study by Lee et al. (2014) and Kemung et al. (2020) identified a crude extract of Streptomyces sp. MJM 10778 (close to $S$. misionensis NBRC 13063) and Streptomyces sp. MUSC 14 was able to show free-radicals scavenging activity reaching $81.2 \% \pm 0.2$ at concentration $10 \mathrm{mg} \mathrm{mL}^{-1}$ and $24.7 \% \pm 2.22 \mathrm{at}$ concentration $4 \mathrm{mg} \mathrm{mL}^{-1}$, respectively. Study by Tan et al. (2019) also found higher free-radicals scavenging activity reaching $42.33 \% \pm 3.98$ at concentration of $4 \mathrm{mg} \mathrm{mL}^{-1}$ from crude extract of Streptomyces sp. MUM212. The difference in potential as an antioxidant in each bacterium is thought to be due to biotic or abiotic pressures that were continuously found in their habitat environment so that microorganisms need to express metabolites with antioxidant activity as a survival mechanism to neutralize environmental conditions that can induce oxidative stress (McKee 1995).

Qualitatively, the RP-HPLC profiles of the two crude extract secondary metabolites had identical profiles. The AIA12 and AIA17 profiles of crude-extract secondary metabolites had the highest absorption at 210 and $214 \mathrm{~nm}$. The absorption at these wavelengths indicates a compound's ownership with one or more peptide bonds in the amido-chromophore group in its molecular structure (Praveen et al. 2008). Several amino acid such as threonine, methionine, and leucine were also detected at these wavelengths (Ezra et al. 2004). In 254 and $276 \mathrm{~nm}$, only AIA12 showed identical peaks. The presence of a detectable peak at this wavelength indicates the possession of aromatic moiety in its molecular structure (Taniguchi et al. 2014). The RP-HPLC profile can also show hydrophobicity properties (Kurnianto et al. 2020b). The AIA12 crude extract appears to be more hydrophobic than AIA17. This was indicated by more peaks, higher intensity and wider area at a retention time of 15-30 minutes. Based on these results, it was estimated that the two extracts have different constituent compounds (presumably peptides). AIA12 crude extract was estimated to contain compounds with more hydrophobic properties and have aromatic groups. Meanwhile, AIA17 contains compounds with more hydrophilic properties. Further purification and identification steps using LC-MS/MS are needed to find out more about the constituent compounds and the characteristics of the compounds contained in the extracts of AIA12 and AIA17. According to Gadde et al. (2017), antibacterial proteins or peptides generally contain cationic and hydrophobic residue. The cationic residue serves to assist the attachment of the peptide to the bacterial cell membrane, while the hydrophobic residue is related to the antibacterial activity by the insertion mechanism into the cell membrane through hydrophobic interactions (Naarmann et al. 2006).

In conclusion, studies of isolates AIA12 and AIA17 showed that they were potential producers of bioactive compounds. They were identified as Streptomyces and had several interesting characteristics such as salt and $\mathrm{pH}$ tolerance ability, production of several enzymes, and bioactive compounds. The crude extract analysis showed that the two isolates could produce bioactive compounds with potential antibacterial and antioxidant agents. As antibacterial agents, both crude-extracts exhibit broadspectrum antibacterial activity against Gram-negative and Gram-positive bacteria. The extract of AIA17 shows considerable antioxidant activity in scavenging DPPH radicals. These potentials suggest that Streptomyces isolated from an unusual niche environment can become a natural product source with a wide range of biological activities.

\section{ACKNOWLEDGEMENTS}

We acknowledge the Minister of Research, Technology, and Higher Education of the Republic of Indonesia for its research funding under contract No. 4418/IT3.11/PN/2018.

\section{REFERENCES}

Abdel-Aziz SH, Awady MEE, Nasr-Eldin MA, Ibrahim HMM, Al Bahnasy ME. 2019. Production and assessment of antioxidant activity of exopolysaccharide from marine Streptomyces globisporus bu2018. Egypt J Bot 59 (3): 645-655. DOI: 10.21608/ejbo.2019.6847.1274.

Abdelghani T. 2017. Production of antibacterial and antifungal metabolites by ( $S$. albovinaceus) Strain no.10/2 and media optimization. Am Intl J Biol 3 (10): 197-203. DOI: 10.15640/aijb.v5n1a1.

Aharonowitz Y. 1980. Nitrogen metabolite regulation of antibiotic biosynthesis. Annu Rev Microbiol 34: 209-233. DOI: 10.1146/annurev.mi.34.100180.001233.

Al Farraj DA, Varghese R, Vágvölgyi C, Soliman Elshikh M, Alokda AM, Hossam Mahmoud A. 2020. Antibiotics production in optimized culture condition using low-cost substrates from Streptomyces sp. AS4 isolated from mangrove soil sediment. J King Saud Univ - Sci 32 (2): 1528-1535. DOI: 10.1016/j.jksus.2019.12.008

Andayani DGS, Sukandar U, Sukandar EY, Adnyana IK. 2015. Antibacterial, Antifungal and anticancer activity of five strains of soil microorganisms isolated from Tangkuban Perahu Mountain by fermentation. Hayati J Biosci 22 (4): 186-190. DOI: 10.1016/j.hjb.2016.01.003.

Arnison PG, Bibb MJ, Bierbaum G, Bowers AA, Bugni TS, Bulaj G, Camarero JA, Campopiano DJ, Challis GL, Clardy J, Cotter PD. 2014. Ribosomally synthesized and post-translationally modified peptide natural products: overview and recommendations for a universal nomenclature. Nat Prod Rep 30 (1): 108-160. DOI: 10.1039/c2np20085f.Ribosomally.

Balouiri M, Sadiki M, Ibnsouda SK. 2016. Methods for in vitro evaluating antimicrobial activity: A review. J Pharm Anal 6 (2): 71-79. DOI: 10.1016/j.jpha.2015.11.005

Bernal MG, Campa-córdova ÁI, Saucedo PE, González MC. 2015. Isolation and in vitro selection of actinomycetes strains as potential probiotics for aquaculture. Vet World 8: 170-176. DOI: 10.14202/vetworld.2015.170-176.

Bibb MJ. 2005. Regulation of secondary metabolism in streptomycetes. $\begin{array}{llll}\text { Curr Opin Microbiol } 8 & \text { (2): 208-215. DOI: }\end{array}$ 10.1016/j.mib.2005.02.016.

Cerny G. 1978. Studies on the aminopeptidase test for the distinction of gram-negative from gram-positive bacteria. Eur J Appl Microbiol Biotechnol 5 (2): 113-122. DOI: 10.1007/BF00498805.

Claesen J, Bibb MJ. 2011. Biosynthesis and regulation of grisemycin, a new member of the linaridin family of ribosomally synthesized peptides produced by Streptomyces griseus IFO 13350. J Bacteriol 193 (10): 2510-2516. DOI: 10.1128/JB.00171-11.

Davelos AL, Xiao K, Flor JM, Kinkel LL. 2004. Genetic and phenotypic traits of streptomycetes used to characterize antibiotic activities of 
field-collected microbes. Can J Microbiol 50 (2): 79-89. DOI: 10.1139/w03-107

Dholakiya RN, Kumar R, Mishra A, Mody KH, Jha B. 2017. Antibacterial and antioxidant activities of novel actinobacteria strain isolated from Gulf of Khambhat, Gujarat. Front Microbiol 8 (DEC): 1-16. DOI: 10.3389/fmicb.2017.02420.

Djinni I, Defant A, Kecha M, Mancini I. 2014. Metabolite profile of marine-derived endophytic Streptomyces sundarbansensis WR1L1S8 by liquid chromatography-mass spectrometry and evaluation of culture conditions on antibacterial activity and mycelial growth. J Appl Microbiol 116 (1): 39-50. DOI: 10.1111/jam.12360.

Ezra D, Castillo UF, Strobel GA, Hess WM, Porter H, Jensen JB, Condron MA, Teplow DB, Sears J, Maranta M, Hunter M. 2004. Coronamycins, peptide antibiotics produced by a verticillate Streptomyces sp. (MSU-2110) endophytic on Monstera sp. Microbiology 150 (4): 785-793. DOI: 10.1099/mic.0.26645-0.

Farris MH, Duffy C, Findlay RH, Olson JB. 2011. Streptomyces scopuliridis sp. nov., a bacteriocin- producing soil streptomycete. Int J Syst Evol Microbiol 61 (Pt 9): 2112. DOI: 10.1099/ijs.0.023192-0.

Felsenstein J. 1985. Confidence limits on phylogenies : An approach using the bootstrap. Evolution (N.Y). 39 (4): 783-791. DOI: 10.1111/j.1558-5646.1985.tb00420.x.

Flórez LV, Biedermann PHW, Engl T, Kaltenpoth M. 2015. Defensive symbioses of animals with prokaryotic and eukaryotic microorganisms. Nat Prod Rep 32 (7): 904-936. DOI 10.1039/c5np00010f.

Gadde U, Kim WH, Oh ST, Lillehoj HS. 2017. Alternatives to antibiotics for maximizing growth performance and feed efficiency in poultry: A review. Anim Heal Res Rev 18 (1): 26-45. DOI: 10.1017/S1466252316000207.

Gebreyohannes G, Moges F, Sahile S, Raja N. 2013. Isolation and characterization of potential antibiotic producing actinomycetes from water and sediments of Lake Tana, Ethiopia. Asian Pac J Trop Biomed 3 (6): 426-435. DOI: 10.1016/S2221-1691(13)60092-1.

Hasani A, Kariminik A, Isaazadeh K. 2014. Streptomycetes : Characteristics and their antimicrobial activities. Int J Adv Biol Biomed Res 2 (1): 63-75.

Huang D, Boxin OU, Prior RL. 2005. The chemistry behind antioxidant capacity assays. J Agric Food Chem 53 (6): 1841-1856. DOI: $10.1021 / \mathrm{jf} 030723 \mathrm{c}$

Huo L, Rachid S, Stadler M, Wenzel SC, Müller R. 2012. Synthetic biotechnology to study and engineer ribosomal bottromycin biosynthesis. Chem Biol 19 (10): 1278-1287. DOI: 10.1016/j.chembiol.2012.08.013.

James NC, Cowley PD, Whitfield AK, Lamberth SJ. 2007. Fish communities in temporarily open/closed estuaries from the warm- and cool-temperate regions of South Africa: A review. Rev Fish Biol Fish 17 (4): 565-580. DOI: 10.1007/s11160-007-9057-7.

Janardhan A, Kumar AP, Viswanath B, Saigopal DVR, Narasimha G. 2014. Production of bioactive compounds by actinomycetes and their antioxidant properties. Biotechnol Res Int 2014: 1-8. DOI: $10.1155 / 2014 / 217030$

Kaweewan I, Komaki H, Hemmi H, Kodani S. 2018. Isolation and structure determination of a new thiopeptide globimycin from Streptomyces globisporus subsp. globisporus based on genome mining. Tetrahedron Lett 59 (4): 409-414. DOI: 10.1016/j.tetlet.2017.12.056

Kemung HM, Tan LTH, Chan KG, Ser HL, Law JWF, Lee LH, Goh BH. 2020. Streptomyces sp. Strain MUSC 125 from Mangrove Soil in Malaysia with Anti-MRSA, Anti-Biofilm and Antioxidant Activities Molecules 25 (15). DOI: 10.3390/molecules25153545.

Kominek LA. 1972. Biosynthesis of novobiocin by Streptomyces niveus. Antimicrob Agents Chemother 1 (2): 123-134. DOI: 10.1128/AAC.1.2.123

Kumala T, Jayuska A, Ardiningsih P. 2015. Uji aktivitas antimikroba dari Actinomycetes 9ISP1 dari spons asal perairan Pulau Randayan. J Kim Khatulistiwa 4 (2): 30-36. [Indonesian]

Kurnianto MA, Kusumaningrum HD, Lioe HN. 2020a. Penapisan actinobacteria akuatik penghasil antibakteri dari ikan bandeng (Chanos chanos) dan belanak (Mugil cephalus) dengan Metode Double-layer Diffusion. J Pascapanen dan Bioteknol. Kelaut. dan Perikan 15 (1): 1-11. DOI: 10.15578/jpbkp.v15i1.647 [Indonesian]

Kurnianto MA, Kusumaningrum HD, Lioe HN. 2020b. Characterization of Streptomyces isolates associated with estuarine fish Chanos chanos and profiling of their antibacterial metabolites-crude-extract. Int Microbiol 2020. DOI: 10.1155/2020/8851947.
Lee DR, Lee SK, Choi BK, Cheng J, Lee YS, Yang SH, Suh JW. 2014. Antioxidant activity and free radical scavenging activities of Streptomyces sp. strain MJM 10778. Asian Pac J Trop Med 7 (12): 962-967. DOI: 10.1016/S1995-7645(14)60170-X.

Lee LH, Zainal N, Azman AS, Eng SK, Ab Mutalib NS, Yin WF, Chan KG. 2014. Streptomyces pluripotens sp. nov., A bacteriocinproducing streptomycete that inhibits meticillin-resistant Staphylococcus aureus. Int J Syst Evol Microbiol 64 (2014): $3297-$ 3306. DOI: $10.1099 /$ ijs. $0.065045-0$

Lewin G, Carlon C, Chevrette MG, Horn HA, McDonald BR, Stankey RJ, Fox brian G, Currie CR. 2017. Evolution and ecology of actinobacteria and their bioenergy applications. Annu Rev Microbiol 70 (1): 235-254. DOI: 10.1016/j.physbeh.2017.03.040.

McKee KL. 1995. Interspecific variation in growth, biomass partitioning, and defensive characteristics of neotropical mangrove seedlings: Response to light and nutrient availability. Am J Bot 82 (3): 299-307. DOI: 10.1002/j.1537-2197.1995.tb12634.x.

Memarpoor-Yazdi M, Asoodeh A, Chamani JK. 2012. A novel antioxidant and antimicrobial peptide from hen egg-white lysozyme hydrolysates. J Funct Foods 4 (1): 278-286. DOI: 10.1016/j.jff.2011.12.004

Naarmann N, Bilgiçer B, Meng H, Kumar K, Steinem C. 2006. Fluorinated interfaces drive self-association of transmembrane $\alpha$ helices in lipid bilayers. Angew Chemie - Int Ed 45 (16): 2588-2591. DOI: $10.1002 /$ anie. 200503567.

Nett M, Ikeda H, Moore BS. 2009. Genomic basis for natural product biosynthetic diversity in the actinomycetes. Nat Prod Rep 26(11): 1362-1384. DOI: $10.1039 / \mathrm{b} 817069 j$.

Nurkanto A, Agusta A. 2015. Identifikasi Molekular dan karakterisasi morfo-fisiologi actinomycetes penghasil senyawa antimikroba. J Biol Indones 11 (2): 195-203. [Indonesian]

Ökesli A, Cooper LE, Fogle EJ, Van Der Donk WA. 2011. Nine posttranslational modifications during the biosynthesis of cinnamycin. $\mathbf{J}$ Am Chem Soc 133 (34): 13753-13760. DOI: 10.1021/ja205783f

Parthasarathi S, Sathya S, Bupesh G, Manikandan M, Kim CJ, Manikandan T, Balakrishnan K. 2013. Isolation, characterization and extraction of antimicrobial compound from marine actinomycete streptomyces hygroscopicus BDUS 49. Res J Biotechnol 8 (3): 40-48. DOI: 10.5829/idosi.wjfms.2012.04.03.5658

Passari AK, Mishra VK, Saikia R, Gupta VK, Singh BP. 2015. Isolation, abundance and phylogenetic affiliation of endophytic actinomycetes associated with medicinal plants and screening for their in vitro antimicrobial biosynthetic potential. Front Microbiol 6 (APR): 1-13. DOI: $10.3389 /$ fmicb.2015.00273.

Pitcher DG, Saunders NA, Owen RJ. 1989. Rapid extraction of bacterial genomic DNA with guanidium thiocyanate. Lett Appl Microbiol 8: 151-156. DOI: 10.1111/j.1472-765X.1989.tb00262.x

Praveen V, Tripathi CKM, Bihari V, Srivastava SC. 2008. Production of actinomycin-D by the mutant of a new isolate of Streptomyces sindenensis. Braz J Microbiol 39 (4): 689-692. DOI: 10.1590/S151783822008000400017 .

Pridham TG, Gottlieb D. 1948. The utilization of carbon compounds by some Actinomycetales as an aid for species determination. J Bacteriol 56 (1): 107-114. DOI: 10.1128/jb.56.1.107-114.1948.

Priya M, Anandaraj B. 2016. 16S rRNA gene characterization of the actinomycete- Streptomyces tuirus, from the estuary region of Ariyankuppam, Puducherry- union territory, India. Int J Pharma Biol Sci 7 (4): B816-B821.

Quinn GA, Banat AM, Abdelhameed AM, Banat IM. 2020. Streptomyces from traditional medicine: sources of new innovations in antibiotic discovery. J Med Microbiol 69 (8): 1040-1048. DOI: 10.1099/jmm.0.001232

Saadouli I, Zendah El Euch I, Trabelsi E, Mosbah A, Redissi A, Ferjani R, Fhoula I, Cherif A, Sabatier JM, Sewald N, Ouzari HI. 2020. Isolation, characterization and chemical synthesis of large spectrum antimicrobial cyclic dipeptide (L-leu-l-pro) from streptomyces misionensisv16r3y1 bacteria extracts. a novel1H NMR metabolomics approach. Antibiotics 9 (5): 1-13. DOI: 10.3390/antibiotics9050270.

Sánchez S, Chávez A, Forero A, García-Huante Y, Romero A, Sánchez M, Rocha D, Sánchez B, Valos M, Guzmán-Trampe S. 2010. Carbon source regulation of antibiotic production. J Antibiot (Tokyo) 63 (8): 442-459. DOI: 10.1038/ja.2010.78.

Sanchez S, Demain AL. 2002. Metabolic regulation of fermentation processes. Enzyme Microb Technol 31 (7): 895-906. DOI: 10.1016/S0141-0229(02)00172-2. 
Ser HL, Palanisamy UD, Yin WF, Chan KG, Goh BH, Lee LH, 2016. Streptomyces malaysiense sp. nov.: A novel Malaysian mangrove soil actinobacterium with antioxidative activity and cytotoxic potential against human cancer cell lines. Sci Rep 6 (March): 1-12. DOI: $10.1038 /$ srep 24247

Shirling E, Gottlieb D. 1966. Methods for characterization of Streptomyces species. Int J Syst Bacteriol 16 (3): 313-340. DOI: 10.20961/ge.v4i1.19180

Singh LS, Sharma H, Talukdar NC. 2014. Production of potent antimicrobial agent by actinomycete, Streptomyces sannanensis strain SU118 isolated from phoomdi in Loktak Lake of Manipur, India. BMC Microbiol 14 (1): 1-13. DOI: 10.1186/s12866-014-0278-3.

Sivalingam P, Hong K, Pote J, Prabakar K. 2019. Extreme environment streptomyces: Potential sources for new antibacterial and anticancer drug leads? Int J Microbiol 2019. DOI: 10.1155/2019/5283948.

Tan LTH, Chan KG, Pusparajah P, Yin WF, Khan TM, Lee LH, Goh BH 2019. Mangrove-derived Streptomyces sp. MUM265 as a potential source of antioxidant and anticolon-cancer agents. BMC Microbiol 19 (1): 1-16. DOI: 10.1186/s12866-019-1409-7.

Tan LTH, Mahendra CK, Yow YY, Chan KG, Khan TM, Lee LH, Goh BH. 2019. Streptomyces sp. MUM273b: A mangrove-derived potential source for antioxidant and UVB radiation protectants Microbiologyopen 8 (10): 1-16. DOI: 10.1002/mbo3.859.
Taniguchi Y, Shinkai S, Nishi M, Murayama H, Nofuji Y, Yoshida H, Fujiwara Y. 2014. Nutritional biomarkers and subsequent cognitive decline among community-dwelling older Japanese: A prospective study. J Gerontol - Ser A Biol Sci Med Sci 69 (10): 1276-1283. DOI: $10.1093 /$ gerona/glt286

Umerska A, Strandh M, Cassisa V, Matougui N, Eveillard M, Saulnier P. 2018. Synergistic effect of combinations containing EDTA and the antimicrobial peptide AA230, an arenicin-3 derivative, on gramnegative bacteria. Biomolecules 8 (4). DOI: 10.3390/biom8040122

Vilches C, Mendez C, Hardisson C, Salas JA. 1990. Biosynthesis of oleandomycin by Streptomyces antibioticus: Influence of nutritional conditions and development of resistance. J Gen Microbiol 136 (8): 1447-1454. DOI: 10.1099/00221287-136-8-1447.

Zhang J, Liu G, Shang NAN, Cheng W, Chen S, Li P. 2009. Purification and partial amino acid sequence of pentocin 31-1, an anti- listeria bacteriocin produced by Lactobacillus pentosus 31-1. J Food Prot 72 (12): 2524-2529. DOI: 10.4315/0362-028X-72.12.2524.

Zothanpuia, Passari AK, Chandra P, Leo V V., Mishra VK, Kumar B, Singh BP. 2017. Production of potent antimicrobial compounds from Streptomyces cyaneofuscatus associated with freshwater sediment. Front Microbiol 8 (JAN): 1-13. DOI: 10.3389/fmicb.2017.00068. 